\title{
A review of FinTech research
}

\section{Atsuyoshi Takeda* and Yoshihiro Ito}

Nagaoka University of Technology, 1603-1, Kamitomioka, Nagaoka, Niigata, 940-2188, Japan

Email: s177010@stn.nagaokaut.ac.jp

Email: itoy@kjs.nagaokaut.ac.jp

*Corresponding author

\begin{abstract}
The aim of this paper is to review previous research on FinTech, which may be broadly understood as financial innovation that uses information technology to provide financial services. The paper describes a review of 88 refereed academic papers on the subject of FinTech published in journals that have high SJR2017 scores. Papers were categorised according to the type of companies leveraging FinTech (existing financial institutions vs. new entrants) and the type of value derived from FinTech innovation (new value-added vs. improved efficiency). Also considered were types of new value-added, geographical focus of the research and research methodologies. The largest number of studies concerned the use of FinTech innovation by new entrants to offer solutions to social issues or build new financial ecosystems. Over half the studies were on FinTech in Asia or the European Union, and the most common methodology employed was the case study.
\end{abstract}

Keywords: FinTech; financial innovation; information technology; IT; technology management; innovation management; financial inclusion; bank marketing; P2P lending; crowdfunding; RegTech.

Reference to this paper should be made as follows: Takeda, A. and Ito, Y. (2021) 'A review of FinTech research', Int. J. Technology Management, Vol. 86, No. 1, pp.67-88.

Biographical notes: Atsuyoshi Takeda is a $\mathrm{PhD}$ candidate in Nagaoka University of Technology. He received his BE in Marine Structures from Osaka Prefecture University, Japan, in 1993, and MBA in International Business from the University of Southern California, in 2006. He has also been working for a general trading company in Japan as a new business developer in the financial business industry since 1993. His current research interests include FinTech, technological innovation and innovation management.

Yoshihiro Ito is a Professor in Management at Graduate School of Engineering, Nagaoka University of Technology, from 2017. He received his BE and ME in Material Engineering from Waseda University, Japan, in 1988 and 1990 respectively, MBA from Hosei University, Japan, in 1998, and PhD in Management from Tohoku University, Japan, in 2005. He worked as a researcher for Canon Inc., Japan, from 1990 to 2006. He was an Associate Professor of Management at Yamagata University, Japan, from 2006 to 2015. His current research interests include strategic management, innovation management and business model innovation. 


\section{Introduction}

\subsection{Aim of this study}

The aim of this paper is to review and provide an overview of previous research on FinTech. The financial crisis of 2008 triggered new financial innovations, known as FinTech, which integrate digital technologies such as the internet, smartphones, and artificial intelligence (AI) with financial services. FinTech offers new value-added and makes it possible to provide services at a lower cost than previously. Existing financial institutions must develop their businesses in step with the financial regulations of the country they operate in. Banks in particular tend to be conservative, and lacking in customer service. Under these conditions, the emergence of FinTech has revolutionised the financial industry and attracted worldwide attention. For these reasons, research studies on FinTech have increased greatly in recent years.

The term 'FinTech' first appeared in the early 1990s. Since then, newspaper and magazine articles on the topic of FinTech have been published at a rate of 3 to 10 times per year (Puschmann, 2017). The first academic papers on FinTech appeared in 2015, and their frequency has increased significantly since then. In 2018, 91 academic papers on FinTech were published.

The term 'financial innovation', which has almost same meaning as FinTech, appeared earlier than 'FinTech', and one or two academic papers were published on financial innovation each year until 2009. Since 2010, however, academic papers on financial innovation have appeared at an average rate of 13 per year. The rapid increase in papers on financial innovation is also indicative of the rise of interest in FinTech in recent years.

This paper reports the results of a review of 88 refereed academic papers on the subject of FinTech, categorised by the type of value derived from FinTech innovation (provision of new value-added vs. improved efficiency) and the type of company leveraging FinTech (existing financial institutions vs. new entrants).

\subsection{Definition of FinTech and overview of previous studies}

A clear definition of FinTech is essential in order to understand its nature and the innovations it delivers. In 2015, when academic papers about it began to appear, there was no clear definition of the FinTech. Then, in 2017, Leong et al. wrote: "With the inexorable march of technological advances and digital transformation, we are now witnessing rampant disruptions in highly regulated sectors such as banking and finance, especially with the development of FinTech, a broad umbrella term that describes disruptive technologies in the financial services sector." Subsequently, Gai et al. (2018) defined FinTech as an emerging technical term that "describes the financial technology sectors in a wide range of operations for enterprises or organizations, which mainly addresses the improvement of the service quality by using information technology (IT) applications." Gomber et al. (2018), offering greater detail, stated, "FinTech is a portmanteau of financial technology that describes an emerging financial services sector in the 21 st century. Originally, the term applied to technology applied to the back-end of established consumer and trade financial institutions. Since the end of the first decade of the 21 st century, the term has expanded to include any technological innovation in the financial sector, including innovations in financial literacy and education, retail banking, 
investment and even crypto-currencies like Bitcoin." Ozili (2018) explained it more simply: "The term 'FinTech' denotes 'financial technology' and is defined as the delivery of financial and banking services through modern technological innovation led by computer programs and algorithms."

This paper adopts a simple definition of FinTech: "financial innovation realized by information technology (IT)." More specifically, in this paper, FinTech as technologies will be referred to as 'FinTech technologies', FinTech as services will be referred to as 'FinTech services'; and FinTech as a phenomenon will be referred to simply as 'FinTech'.

Although academic papers on FinTech are rapidly increasing in number (see Figure 1), literature reviews on FinTech remain few. Regarding technical aspects of FinTech, Lee et al. (2018) describe innovative business models and low-cost services created by FinTech companies as well as blockchain technology, which makes possible enormous efficiency improvements; they also draw attention to issues such as consumer protection and fraud that will need to be addressed in the future. Dhar and Stein (2017) describe the possibilities of FinTech platforms, which are advancing rapidly as alternative means of offering financial services. Nakashima (2018) reports on the creation of a new type of auto loans fusing FinTech technology with internet of things (IoT) technology, which holds the promise of helping improve the lives of impoverished people.

Figure 1 The number of FinTech academic papers

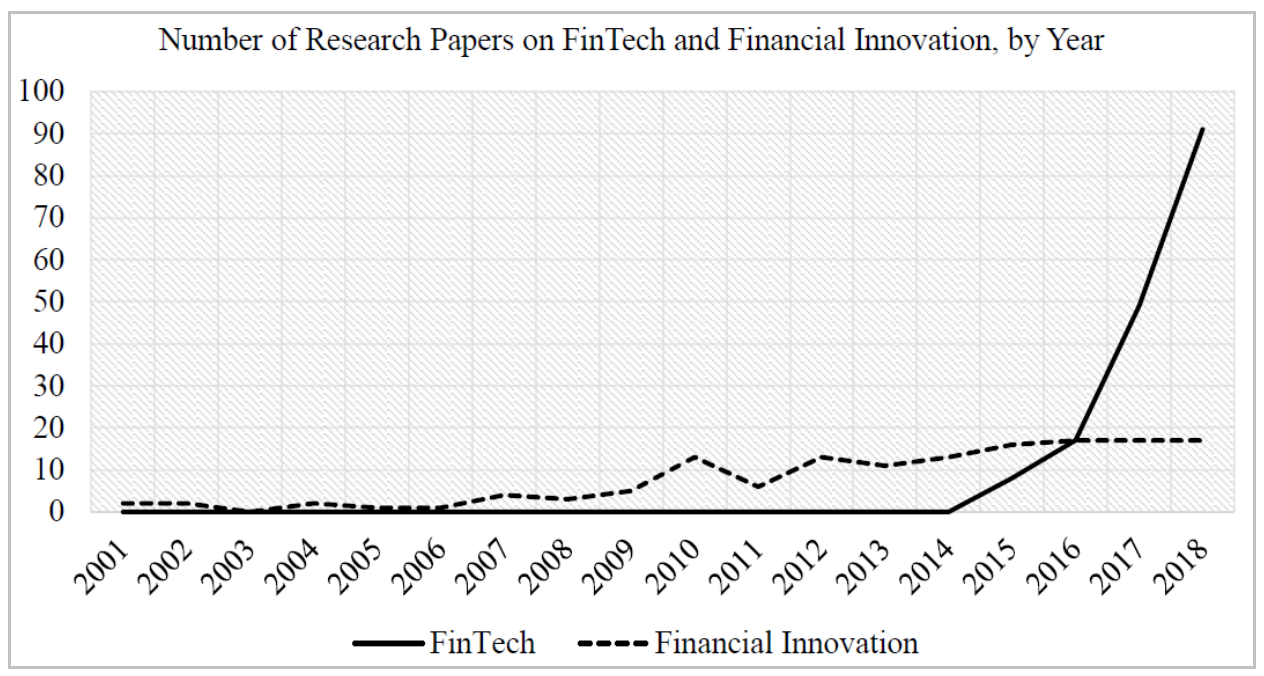

Source: Author

Regarding regulation issues around of FinTech, $\mathrm{Ng}$ and Kwok (2017) describe regulations needed for Hong Kong to maintain its advantages as a global financial centre as FinTech flourishes. Romanova et al. (2018) describe how FinTech companies are improving the quality and efficiency of financial services through compliance with European Payment Services Directive 2 (PSD2); they also report how PSD2 has enabled the provision of new value-added, by promoting a high degree of standardisation in financial services. Van Loo (2018) stresses the need for regulators to incorporate the concepts of consumer protection, service stability, and competition among firms in order 
to further advance FinTech. Magnuson (2018) shows how the application of existing regulations to FinTech companies with vulnerable capital structures impedes the progress of FinTech. Similarly, Savoie and Hoffman (2018) and Upton (2018) discuss the pros and cons of applying a special-purpose national bank (SPNB) charter to FinTech companies in the USA.

As seen above, most existing literature reviews focus chiefly on technical or regulatory aspects of FinTech. The present paper adopts a different perspective, focusing on the types of value derived from FinTech innovation and the types of companies using FinTech to deliver that value.

\subsection{Research method}

The search for previous studies to be reviewed for this paper was conducted during the period February-April 2019, using Elsevier's Scopus database of academic papers. One hundred seventy-three refereed academic papers in English were identified that included the term FinTech in their titles or keywords. From these, papers published in journals with a score of 0.12 or higher in the 2017 SCImago Journal Rank (SJR) were selected. The SJR is a measure of the scientific influence of scholarly journals. SJR scores of less than 0.12 typically indicate general magazines rather than academic journals. The reason SJR was used as a selection criterion rather than impact factor (IF) is that FinTech papers are spread over multiple fields, and it was judged that SJR, which applies weighting and correction across fields, could better identify important papers. This selection process resulted in a sample of 88 FinTech papers.

Table 1 shows the number of papers reviewed in each of four categories. Type A are papers about existing financial institutions using FinTech to provide new value-added. Type B are papers about existing financial institutions using FinTech to achieve improved efficiency. Type $\mathrm{C}$ are papers about new entrants using FinTech to provide new value-added. And Type D are papers about new entrants using FinTech to achieve improved efficiency. 'New entrants' are defined as companies that have entered the finance industry by leveraging FinTech technology; the term 'new entrants' is used to distinguish these companies from 'existing financial institutions', which were already established in the finance industry prior to the advent of FinTech. The term 'FinTech companies' is also used for 'new entrants' in this paper. 'FinTech companies' refers to companies that provide innovative financial services, mainly to consumers, with FinTech as their core technology.

It can be seen that papers of Type $C$ (provision of new value-added by new entrants) were the most numerous, while papers of Type B (improved efficiency by existing financial institutions) were the fewest in number.

Table 1 also breaks down the number of papers by type of new value-added, region, and research method. 48 of 66 papers on new value-added were 'research on providing new value-added through new technologies'. By region, Asia and the EU each accounted for 26 studies. These two regions together made up 59\% of the studies. The most common research method employed was the case study, which was used in 29 papers. 
Table 1 FinTech papers by category

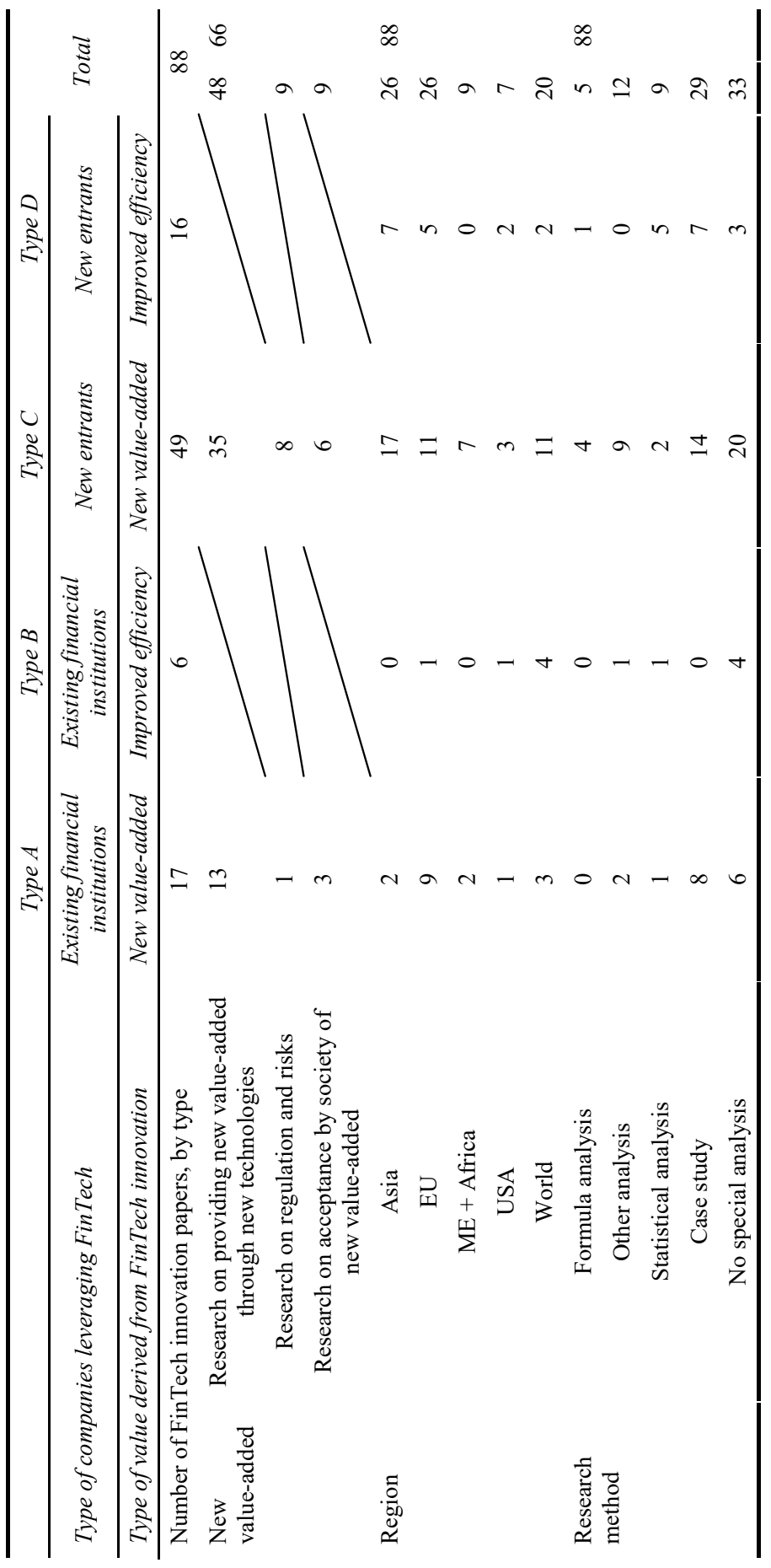




\section{Review of previous research papers}

In this section, previous research studies on FinTech are described by category.

\subsection{Provision of new value-added by existing financial institutions (Type A)}

\subsubsection{Research on providing new value-added through new financial technologies}

Most of the academic papers of this type emphasise how existing financial institutions have strategically accumulated FinTech technologies internally and used them to provide new value-added to customers. Sloboda et al. (2018), using the example of Ukrainian banks, point out that retail banks are more profitable, more stable, and safer when they develop retail banking services based on FinTech innovation and transparency. Similarly, Wonglimpiyarat (2017a) introduces systematic innovation achieved by Thai banks using strategic FinTech technologies. Dimbean-Creta (2018) argues that while FinTech has an overall negative impact on the financial industry, existing financial institutions, because they have historically invested in IT, are likely to learn FinTech technologies to advance their own technologies and services. Costa-Climent and Martínez-Climent (2018) introduce European commercial banks that have adopted FinTech technologies in order to actively engage in corporate social responsibility (CSR) and make the banking business model more sustainable.

Some researchers emphasise that enterprises should focus on technologies that are suited to their own particular situation when they accumulate FinTech technologies. Trelewicz (2017) gives the example of an existing financial institution that uses big data analytics to create new credit. Similarly, Lui and Lamb (2018) show how existing financial institutions use AI to personalise customer service and provide more efficient and customer-centric financial services. $\mathrm{Du}$ (2018) argues that in order to raise productivity and increase customer satisfaction, existing US credit unions should participate in the new financial ecosystem by using new mobile payment methods that FinTech technologies have made possible. Caron (2018) argues that payment providers, including existing financial institutions, must keep up with payments innovation in order to remain competitive.

On the other hand, other studies point out that some existing financial institutions have opted to forego learning FinTech technologies themselves and have instead partnered with or acquired FinTech companies strategically in order to participate in the new financial ecosystem that FinTech platform operators have built. Ashta and Biot-Paquerot (2018) give examples of existing banks that have developed partnerships with FinTech companies to create new services. Anagnostopoulos (2018) introduces examples of banks that recognise FinTech-driven financial business transformation as a good opportunity to offer added value and have joined the new financial ecosystem by strategically partnering with FinTech companies and seeking to influence the FinTech regulatory environment. Sinha (2017) identifies innovative FinTech technologies that banks in Singapore should adopt for the future. Similarly, Zalan and Toufaily (2017) and Coetzee (2018) also argue that existing financial institutions should enter partnerships with FinTech companies in order to acquire FinTech technologies and join the new financial ecosystem. 


\subsubsection{Research on regulation and risks}

Some academic papers cover system security risks and regulation needed in the financial industry to allow existing financial institutions to continue to work on FinTech service. Chiu (2017) shows how monetary policy designed to revitalise the economy by promoting competition among FinTech platform operators may neglect consumer protection, and how this requires regulation of the active pursuit of financial innovation.

\subsubsection{Research on society's acceptance of new value-added}

Some academic studies explore from the user's perspective whether society can accept new FinTech technologies and the value-added they offer. Stewart and Jürjens (2018) use a technology acceptance model (TAM) to perform a factor analysis of factors that increase customer satisfaction toward FinTech services. They show that acceptance of FinTech services remains low because people who are strongly interested in controlling their own data feel uneasy about protection of personal information when using FinTech technologies. On the other hand, Duma and Gligor (2018) surveyed the 'digital native' generation (Generation $Z$ ) regarding online transactions and acceptance of virtual currencies/blockchains, and found that this generation, regardless of the complex technology underlying FinTech services, enjoys the freedom, mobility, coolness, and nimbleness that FinTech brings, and accepts innovation and continuous technological development very naturally. Pousttchi and Dehnert (2018) used a grounded theory approach to investigate the impact of digitisation on consumer decision-making in retail banking; they argue that, in order to compete with FinTech companies, existing financial institutions must use a data-driven approach that enables them to provide services to the right customers in the right way and at the right time.

In summary, research studies on existing financial institutions providing new value-added to customers though FinTech technologies are dominated by cases of existing financial institutions recognising the new value-added made possible by FinTech and employing it strategically in order to join the new financial ecosystem. Specifically, several academic papers point out that existing financial institution has three choices: to develop or acquire FinTech technologies on their own, to enter into partnerships with FinTech companies, or to acquire FinTech companies. Other prominent research topics found in these papers are the degree to which FinTech services are accepted by consumers, and the security measures and regulatory framework needed to protect consumer privacy and protect personal assets from criminal activity.

\subsection{Improved efficiency by existing financial institutions (Type B)}

Here, we review previous research that shows examples of existing financial institutions' efforts to use FinTech technologies to improve convenience, improve operational efficiency and reduce costs.

As examples of improved efficiency, Dimbean-Creta (2017) show how FinTech technologies - particularly blockchain technologies - are realising productivity and efficiency improvements in banking and financial services, while Kotarba (2016) shows how banks have improved customer relationship management (CRM) efficiency by utilising FinTech technologies while complying with regulations in response to social demands. Sutherland (2018) shows how an entire industry has been able to use credit 
more efficiently and accurately by collecting and analysing data accumulated by several major US equipment finance companies and sharing it as credit information.

As an example of cost reduction, Nam et al. (2016) show that mobile banking services using new technology function as digital branches, offering the same value as physical bank branches, and suggest that banks can reduce costs significantly by closing branches. Brammertz and Mendelowitz (2018) argue that transaction costs can be greatly reduced by using the smart contract function of blockchains for banking transactions. Geranio (2017) describes the reasons why securities traders have invested in blockchain technologies (to be ready for the entry of potential new competitors from high tech, telecommunications, and other industries) as well as the state of adoption of blockchain technologies and related issues. These six research papers are the only papers in the sample on this topic.

\subsection{Provision of new value-added value by new entrants (Type C)}

\subsubsection{Research on providing new value-added through new technologies}

Numerous studies describe how FinTech companies utilise new technologies to create service platforms at levels previously unseen and provide new value-added to customers via financial ecosystems based on these platforms. Puschmann (2017) describes the revolutionary changes in the finance industry as a whole caused by digitalisation of financial services using FinTech technologies, while Schulte and Liu (2018) describe how further progress can be expected from the linkage of FinTech with IoT utilising vast volumes of data, with AI, with quantum computing, and with other technologies. Lee and Lee (2017) introduce a financial ecosystem centred on a service platform built by Korean FinTech companies. Shim and Shin (2016) use actor network theory (ANT) to show how FinTech companies have created a financial ecosystem in step with Chinese monetary policy, contributing to the promotion of China's financial industry.

We next introduce research studies that categorise FinTech companies on various axes. Lee and Shin (2018) describe the existence of a new financial ecosystem built around traditional financial institutions, technology developers, governments, and customers, with FinTech companies at the core, and classify new business models such as payments, asset management, crowdfunding, and peer-to-peer (P2P) lending that have been created in the new financial ecosystem. Gozman et al. (2018) describe the competitive strategy of FinTech companies through a cluster analysis of FinTech's core services and component technologies. Riikkinen et al. (2019), in a component study of service innovation stacks at ten FinTech startups in Finland, explain the service-innovation approaches of FinTech companies and analyse the origins of the innovative services that they create. Gimpel et al. (2018) classify the service content of consumer FinTech companies in Germany by non-functional characteristics. Gomber et al. (2018) map FinTech technologies and services on a $2 \times 2$ matrix, with destroyers and complementors of markets and business competition on the vertical axis and extensions of and additions to customer experience on the horizontal axis, in order to show the direction in which FinTech is moving. Gomber et al. (2017) classify FinTech services using a three-dimensional digital finance cube that consists of a business function axis, a technology concept axis, and a corporate structure axis. Gai et al. (2018) research and analyse FinTech issues from five technical aspects: data-oriented methods, facility and equipment development, application design, service model placement, and 
security and privacy. They point out that data-driven applications and related hardware will have a significant impact on the finance industry. Finally, Stoeckli et al. (2018) use a grounded theory approach to evaluate insurance services incorporating various insurance technology (InsureTech) innovations.

In addition to the above, there are research papers with examples of new value-added provided through the use of FinTech companies' technologies and platforms. Kang (2018) and Son and Kim (2018) present a case of payment services provided exclusively by financial institutions being replaced with mobile payment services using FinTech technologies. Dorfleitner et al. (2017) introduce a small business lending function that uses an online invoice platform. Petrushenko et al. (2018) point out that the transparent fee structures, quick account opening, and real-time updating of account information that FinTech companies provide are important for improving the quality of international money transfer services.

There are also examples of the provision of new value-added in internet-related services. Mamonov and Malaga (2018) introduce equity crowdfunding as an investment platform for venture companies, while Berger et al. (2018) discuss the imitation mechanisms of social trading platforms, which allow even an amateur investor to achieve the same results as a successful investor. In addition, there are examples of new value-added related to virtual currencies. Adhami et al. (2018) discuss the determinants of successful initial coin offering (ICO) funding in Europe, while Yue et al. (2019) describe the development of the Bitcoin market in Asia, including the evolution of Bitcoin exchanges.

Next is research on 'financial inclusion', which can be defined as efforts to enable all people to access and use basic financial services such as credit, savings, insurance, payments, and remittance at an affordable cost. Before the spread of mobile devices and FinTech technologies, the majority of people in developing countries could not use financial services. However, FinTech innovation is now bringing financial services closer to everyone. Bollinger and Yao (2018) describe FinTech platform companies that provide lending and other financial services to the poor (microfinance) that traditional financial institutions did not provide; this business model has contributed greatly to financial stability in developing countries. Larios-Hernández (2017) state that lowering the cost of financial services using blockchain technology helps to achieve financial inclusion. According to Iman (2018), the realisation of financial inclusion in a region depends on the region's state of development at the time FinTech is introduced. In a region that lacks a mobile payment infrastructure, FinTech technologies can be efficiently invested in to help achieve financial inclusion. On the other hand, he points out that it is not the case that any region can realise financial inclusion simply by having smartphones and FinTech services.

Four studies, starting with Leong et al. (2017), investigate financial inclusion in China. Before FinTech, Chinese banks did not offer financial services for university students, who had no income. Leong et al. (2017) show how an e-commerce company used FinTech technologies to build a proprietary scoring model that aggregates and analyses purchasing data, student information provided by government-designated institutions, data provided by other FinTech companies, and property information; by using this scoring model, Chinese university students can access microfinance. Qi and Xiao (2018) introduce the case of Ant Financial, which offers mobile payment and microfinance to people who cannot access traditional banking services. Chen (2016) explains that Ant Financial's FinTech services have been successful not just because of 
their technology, but because the company responded to consumers' strong demand for financial inclusion in a timely manner. Going one step further, Gruin and Knaack (2019) show how the Chinese Communist Party, with the aim of spurring economic development and maintaining party control, promoted the realisation of financial inclusion using FinTech technologies.

The realisation of financial inclusion has been eagerly awaited and welcomed in developing regions such as the Middle East, Africa, and South Asia. Gabor and Brooks (2017) and Ozili (2018) discuss financial inclusion in the Middle East and North Africa. Burns (2018) takes M-PESA, which leads the mobile money revolution in sub-Saharan Africa, as an example of a contactless mobile phone-based money transfer, payment, and microfinancing service in a country that lacked a financial and payment infrastructure, Kenya. A key success factor for M-PESA in Kenya, in addition to the widespread use of networks and smartphones, was not loose government regulation, but rather the creation of an innovative system that allows both FinTech technologies and services to survive in a regulatory framework designed to convert remittance funds into trusts and to prevent activities like money laundering. Burns (2018) points out that financial inclusion has increased significantly thanks to such innovation. Rastogi (2018) describes M-Kopa Solar, an innovative energy-supply service that uses M-PESA's mobile payment function to serve impoverished consumers in Africa. Ranade (2017) describes how financial inclusion was realised and FinTech advanced through adoption of JAM (short for Jan Dhan-Aadhaar-Mobile), an Indian government initiative that utilises FinTech technologies to link Jan Dhan Vojana bank accounts, Aadhaar ID cards, and mobile phones and smartphones. Sinha et al. (2018) also introduce examples of financial inclusion in India. Kshetri and Voas (2018) found that in developing countries, the use of blockchain technology by banks reduces fraud and corruption, enables people to legally protect their assets, and offers the world's poorest people property-backed investment opportunities.

There is also research on the disadvantages of financial inclusion. Davis et al. (2017), for example, show that the introduction of FinTech technologies-facilitated financial inclusion in Indonesia has brought increased financial risk in areas such as credit loss and money laundering.

As these papers show, financial inclusion has been studied as a representative example of FinTech because of its large social impact in developing countries.

\subsubsection{Research on regulation and risks}

Here, we introduce research on risk management and the establishment of regulations to protect and maintain the value-added provided by FinTech companies. FinTech companies that provide services in place of existing financial institutions are strongly differentiated from traditional financial institutions because they overturn common sense, and for this reason they have gained support from consumers. But at the same time, it is necessary for regulators to regulate FinTech companies so that the secure system of financial transactions that has been built up over the years is not destroyed.

As an example of research in the Europe region, Minto et al. (2017a) offer policymakers a theoretical framework for the development of regulation suited to FinTech services consisting of a four-step filtering process of: 
1 examining FinTech services and their economic function

2 considering the disruptive potential of a financial innovation

3 identifying the processes of disintermediation

4 identifying the processes of decentralisation.

As well, Minto et al. (2017b) describe the scope and goals of regulation of FinTech companies and the strategies used by regulating authorities in response to advances in FinTech technologies. Karakas and Stamegna (2018) describe European efforts to create a regulatory framework capable of balancing regulators' support for FinTech innovation with consumer protection and financial stabilisation in order to maintain Europe's advantages in the field of finance. Currie et al. (2018), in a study on regulatory technology in the UK financial services industry, show that regulatory technology is essential to meet the regulatory obligations that regulators and investors desire.

As an example of research in the USA, Mooney (2018) introduces examples of how FinTech technologies can be used to support laws and regulations for safe financial transactions.

As an example of research in China, where FinTech has made remarkable progress, Deng et al. (2018) argue that ICO regulations should change, as the total ban on ICOs in China hinders technological development. Yang and Li (2018) also argue that China's existing regulatory framework should be complemented by technology-driven regulations (RegTech) that differ from existing regulations, in order to further develop FinTech technologies and services in China and effectively improve the quality and efficiency of financial regulation. Yoon and Jun (2019) point out that in South Korea, regulatory measures taken to clarify responsibility and prevent fraud in the payment schemes of both FinTech providers and existing payment providers is the most cost-effective fraud prevention measure.

As these papers show, groundbreaking FinTech technologies and services, rather than being suppressed by regulation, use regulation effectively to improve convenience and gain trust from customers.

\subsubsection{Research on acceptance by society of new value-added}

Lee (2017) presents the results of a customer acceptance survey using TAMs for P2P lending services provided by Korean FinTech companies. Li et al. (2017) introduced keyword analysis utilising text mining to identify trends in FinTech services; Ryu (2018) used the theory of reasoned action (TRA) to conduct factor analysis of intention to continually use FinTech services such as mobile payments, mobile funds transfers, P2P lending, and crowdfunding; and Jeong et al. (2018) analysed consumer acceptance of mobile funds-transfer services using fingerprint authentication, using the TAM. Lee et al. (2019) used the TAM and the mobile payment service user acceptance model to analyse interrelations between user awareness and retailer awareness in consumer-platform mobile payment services having network effects. Saksonova and Kuzmina-Merlino (2017) discuss the acceptance of FinTech services in Latvia.

These academic papers argue that FinTech companies competing on the basis of technology, in order to stably provide innovative financial services that have not existed before, require not only the provision of useful services but also the protection of personal assets and privacy in order to be accepted by consumers. 


\subsection{Improved efficiency by new entrants (Type D)}

Here, we review previous research on FinTech innovation by FinTech companies that achieves improved efficiency.

Some papers present cases in which FinTech companies provide services as an alternative to banks. These services are mainly alternative lending, for example P2P lending and crowdfunding. Alternative lending are of two types: 'balance sheet lending', in which FinTech companies themselves raise funds for lending from individuals and corporations, and 'marketplace lending', in which FinTech companies use their own internet sites to match lenders to borrowers, without committing any of their own funds. P2P lending and crowdfunding are examples of marketplace lending; the process of matching borrowers and lenders involves collecting various information and data about borrowers on the internet, using big data-based scoring models to create credit scores, and providing mobile applications that make it easy for users to lend and borrow. New-entrant FinTech companies use their own FinTech platforms to offer services in areas where customers were highly dissatisfied with services provided by existing financial institutions; such dissatisfaction involved things like inability to borrow money, complex and confusing processes, and inconvenience. Cai (2018) discusses the crowdfunding platform as an alternative to traditional financial institutions. Much research on this topic has been done in Europe. Maier (2016) explains the reasons that FinTech companies are acting as banking alternatives in the UK: convenience (speed, flexibility and availability) and transparency (process clarity and efficiency). Small and medium-sized companies in particular value these, and give them as reasons for switching from bank borrowing to P2P lending. Sybirianska et al. (2018) also show how consumers and small businesses in the UK have turned to P2P lending and crowdfunding as a replacement for bank loans, and how banks are moving to incorporate such platforms in their own lending. Martínez-Climent et al. (2018) employ bibliometric analysis to show how crowdfunding platforms have attracted attention as an alternative to banks.

Turning to other countries, Jagtiani and Lemieux (2018) introduce LendingClub, the most successful P2P lender among emerging FinTech companies in the USA. FinTech loan platforms like LendingClub are used by customers who are dissatisfied with other available services, such as people living in areas where the number of bank branches has decreased or where high population density means that it takes a long time to receive service. Customers value LendingClub's convenience and high service quality, which explains why the consumer loan business is growing as an alternative to traditional bank lending. Wonglimpiyarat $(2017 \mathrm{~b}, 2018)$ describes the use of crowdfunding in Thailand as an alternative to entrepreneur financing based on Thailand 4.0, the foundation of the Thai entrepreneur innovation system. Tao et al. (2017) show how P2P lending in China that incorporates offline and online data serves as an alternative to traditional bank loans. Huang (2018) investigated a number of P2P lending related issues and summarised the China Financial Supervisory Authority's tightening of lending restrictions.

On the other hand, some papers caution about negative effects of the rise of such alternative lending. Langley and Leyshon (2017) warn that crowdfunding in the UK threatens to replace and destroy existing funding instruments while adapting to regulations. Zetzsche and Preiner (2018), in discussing the regulation of crowdfunding, which has emerged as an important financing alternative for small and medium-sized enterprises in Europe, note that crowdfunding is restricted internationally due to different legal requirements in the financial sectors of different countries even within Europe. 
As this kind of alternative lending continues to flourish, FinTech companies as an alternative to banks will also function socially as 'shadow banking'. Shadow banking offers a remedy for companies or individuals that cannot obtain loans through normal routes, but if it expands too greatly, it will not be possible to control the leverage provided to the world, which would cause major problems. Buchak et al. (2018) describe how, in the USA, FinTech lenders such as QuickenLoans function as shadow banking that bypasses regulations. They lend to low-income consumers who are unable to borrow from regular banks due to strict lending regulations. Rather than taking out banks' mortgages, which involve complicated contracts with banks and take time to execute, such consumers use similar products offered by FinTech companies, even if the interest rates are high.

Research on FinTech innovation made possible by new technology is not limited to alternative lending. FinTech platform companies are making rapid progress as alternatives to banks by lowering payment fees through the use of new payment technologies. Jun and Yeo (2016) introduce a 'two side platform strategy' for sellers and buyers that utilises a payment platform built by a Korean FinTech company, while Tsai and Peng (2017) discuss the regulation of online supply chain finance that utilises FinTech technologies developed by a Chinese manufacturer. Stern et al. (2017) describe how mobile payment has already become an alternative to electronic payment and cash in China, and how the mobile payment infrastructure has helped alternative lending to grow. Gatteschi et al. (2018) introduce an alternative application for insurance contracts using 'InsureTech', which utilises the ability to record transactions between blockchain network participants.

As the above shows, there have been many studies on how FinTech companies equipped with new technologies can replace existing financial institutions by improving business system efficiency. In particular, alternative lending that uses the internet, such as crowdfunding and P2P lending by FinTech platform companies, has attracted a great deal of interest and become a major theme in FinTech research.

\section{Discussion}

\subsection{Findings from of the review of the papers}

Key points from the literature review of 88 refereed academic papers are summarised below, by type.

\subsubsection{Type A}

Studies on the provision of new value-added by existing financial institutions (Type A) show that existing financial institutions are strategically incorporating FinTech in order to improve customer satisfaction, which has deteriorated in comparison to the services provided by FinTech companies. With regard to the method of incorporating FinTech, Ashta and Biot-Paquerot (2018) and Zalan and Toufaily (2017) argue that partnering with FinTech companies is an appropriate approach. Trelewicz (2017) and Lui and Lamb (2018), on the other hand, argue that financial institutions should attempt to develop FinTech technologies in-house through proactive technological investment. Which method is better could depend on the scale of available management resources: an 
existing financial institution that possesses abundant internal resources could carry out development in-house, while one with fewer internal resources might have no choice but to access external resources through partnerships.

\subsubsection{Type $B$}

Studies on the provision of improved efficiency by existing financial institutions (Type B) were few in number, suggesting that existing financial institutions tend not to attempt FinTech innovation because they consider there to be little room for improvement in their own operations. In addition, it is difficult to incorporate new FinTech technologies into the vast information systems already being used by existing financial institutions in their business operations. Over the long run, however, existing financial institutions will need to incorporate FinTech in order to maintain competitive advantage. Accordingly, while research in this field is relatively scarce at present, it can be expected to increase in the future.

\subsubsection{Type $C$}

Studies on the provision of new value-added by new entrants (Type C) show that new entrants utilise FinTech technologies to develop solutions to social issues or to build new financial ecosystems. This category contained the largest number of papers, accounting for over half of all papers reviewed. This is likely due to the large number of Type C examples from the business world and the fact that new entrants are cooperative in providing information to researchers. In the area of solutions to social issues, numerous studies concerned financial inclusion. As Iman (2018) shows, FinTech innovation has helped impoverished nations. Accordingly, in light of their social significance and the large number of studies (16 of the 88 papers reviewed are related to financial inclusion), financial inclusion can be said to be one of the most important topics in FinTech research. At the same time, as noted by Lee and Shin (2018), FinTech companies play an important role in the development of new financial ecosystems incorporating engineers, government agencies, financial customers, and existing financial institutions that aim to improve customer satisfaction and advance the financial industry. In these ways, new entrants are developing and employing FinTech innovations to create solutions that address current social and industry issues in various regions of the world.

\subsubsection{Type D}

Studies on the provision of improved efficiency by new entrants (Type D) show how new entrants, not existing financial institutions, are using FinTech innovations to provide FinTech services such as crowdfunding and P2P lending. As Jagtiani and Lemieux (2018) point out, these services are popular despite their high interest rates because they make it easier and quicker to borrow funds than through traditional bank finance. It is easier for a FinTech company to obtain permission to enter the lending business than it is to obtain a banking license. For this reason, Buchak et al. (2018) show, a kind of shadow banking system has appeared that enables even businesses that cannot secure lending at normal interest rates to borrow working capital. With this, however, comes the risk that shadow banking can lead to a severe economic downturn by destroying a region's financial system. This is an example of FinTech innovation having a serious negative 
effect on society. There will be a need in the future for research that evaluates the specific content of regulations in individual regions from this point of view.

\subsubsection{Region and research method}

The categorisation of studies by region shows that numerous studies are on FinTech in Asian nations and the EU. Many Asian nations are aggressively adopting FinTech because they have lacked a well-developed financial infrastructure up to now. The large number of European studies is due to the wealth of case studies available for research in the EU, which includes Britain and Germany, where numerous FinTech companies have been established, as well as Eastern European nations where the major existing financial institutions continue to be highly influential. Another factor is that Britain is promoting the activities of its FinTech companies in order to maintain its status as a financial centre.

In terms of research method, most of the papers reviewed employed case studies. This may be due to the ease of conducting case studies as well as the fact that the case study method is suitable in light of the relatively small number of FinTech innovating firms. It is hoped that studies employing other research methods will increase in number in the future.

\subsection{FinTech technological aspects and technological management}

The main FinTech technologies covered in the reviewed studies are blockchain technology, authentication technologies, application programming interfaces (APIs), payment technologies, mobile technologies, big data analytics and processing and AI. The distinguishing features, methods of use, and other matters related to these are explained below.

The largest number of studies reviewed was about blockchain technology (followed by payment technologies, mobile technologies, and big data analytics and processing). The large number of studies on blockchain technology - 15 of the 88 papers reviewed was due to this technology's novelty and expectations that it will lead to lower costs. There were three types of papers on blockchain technology: general studies, and papers that focused on cryptocurrencies or smart contracts. Examples of that latter two are Adhami et al. (2018), on cryptocurrencies such as Bitcoin and ICOs, and Brammertz and Mendelowitz (2018), concerning smart contracts intended to reduce banking transaction costs. As implementation of blockchain technologies is at an early stage, related research can be expected to increase in the future.

There were very few studies on authentication technologies and APIs. Among the papers reviewed, none treated APIs as a distinguishing feature of FinTech technologies, and only one treated authentication technologies as such. However, although researchers appear to already consider APIs as a generic technology, APIs are essential for connecting computer systems with each other, and are therefore vital to FinTech innovation.

Payment technologies and mobile technologies are fundamental to FinTech. Mobile payment, a type of FinTech service that combines these two technologies, was discussed in many of the studies reviewed, probably because its use is spreading in the real world. As Du (2018) points out, mobile payment incorporates mobile devices, point-of-sale (POS) devices or near-field-communication (NFC) technologies, mobile applications and short message services (SMS). 
Technologies for the processing and analysis of big data are used to provide new value through high-speed analysis of unstructured, informal data at the petabyte level, including various types and formats. Specifically, they are used in credit scoring systems for P2P lending, as pointed out by Tao et al. (2017), and fraud detection by auditors, as shown by Gai et al. (2018).

Finally, AI technology is used in forecasting and decision-making for financial services. Qi and Xiao (2018) describe a case study in which Ant Financial uses AI internally for purposes such as reducing the payment loss rate and providing outstanding customer service.

It will be interesting to see how the above FinTech technologies are applied in the future to bring financial services closer to consumers' needs.

\subsection{This paper's significance, contributions and limitations}

This paper has reviewed previous research on FinTech categorised by the type of companies leveraging FinTech and type of value provided by FinTech innovation. As noted in the introduction, previous reviews of FinTech research have focused on technical aspects of FinTech or on regulations to protect assets and privacy. This paper represents the first to attempt to reveal more about FinTech innovation by grouping studies according to who leverages FinTech and the types of value FinTech innovation generates. This constitutes a significant and unique contribution to understanding of the use of FinTech in our world.

More specific contributions of the paper include the following. First, it contributes to the academic fields of finance, information engineering, and social science by providing a bird's-eye view of FinTech research as a whole. Second, by elucidating what FinTech researchers consider to be FinTech innovation, it contributes to management research in the field of finance, which is generally considered to be not conducive to innovation. Third, it provides practical value to researchers, practitioners and IT engineers. For researchers, it identifies domains in which FinTech research is important but has not yet advanced. For practitioners, it provides information and knowledge for judging the business value and effects of FinTech. For IT engineers, it suggests technical IT skills that will be needed in the finance industry in the future.

A limitation of this study is its dependence on searching a database to select the papers to be reviewed. It is possible that some influential papers might have been excluded from review if they were not included in the subject of the search. On the other hand, this research method has the advantages of selecting papers from an impartial perspective and of enabling reproducibility for some time.

\section{Conclusions}

This paper has categorised and reviewed previous studies on FinTech from the perspectives of the type of companies leveraging FinTech (existing financial institutions vs. new entrants) and the type of value derived from FinTech innovation (provision of new value-added vs. improved efficiency). This categorisation provides a new perspective on what FinTech innovation is.

The largest number of studies concerned the provision of new value-added by new entrants. These studies investigated and described how new entrants are utilising FinTech 
to provide solutions to social issues or build new financial ecosystems. Specifically, numerous studies concerned realisation of financial inclusion for the poor and building of new financial ecosystems to improve customer satisfaction. The most common regions studied were Asian nations and the EU, and the most common research method employed was the case study. The most common FinTech technology studied was blockchain technology.

It is expected that research studies on FinTech, which remain relatively few in number, will increase in the future, especially as FinTech initiatives by existing financial institutions increase.

\section{Acknowledgements}

This work was supported by Trust Forum Foundation and Ishii Memorial Securities Research Promotion Foundation.

\section{References}

Adhami, S., Giudici, G. and Martinazzi, S. (2018) 'Why do businesses go crypto? An empirical analysis of initial coin offerings', Journal of Economics and Business, Vol. 100, pp.64-75.

Anagnostopoulos, I. (2018) 'Fintech and regtech: Impact on regulators and banks', Journal of Economics and Business, Vol. 100, pp.7-25.

Ashta, A. and Biot-Paquerot, G. (2018) 'FinTech evolution: strategic value management issues in a fast changing industry', Strategic Change, Vol. 27, No. 4, pp.301-311.

Berger, E.S.C., Wenzel, M. and Wohlgemuth, V. (2018) 'Imitation-related performance outcomes in social trading: a configurational approach', Journal of Business Research, August, Vol. 89, pp.322-327.

Bollinger, B. and Yao, S. (2018) 'Risk transfer versus cost reduction on two-sided microfinance platforms', Quantitative Marketing and Economics, Vol. 16, No. 3, pp.251-287.

Brammertz, W. and Mendelowitz, A.I. (2018) 'From digital currencies to digital finance: the case for a smart financial contract standard', Journal of Risk Finance, Vol. 19, No. 1, pp.76-92.

Buchak, G., Matvos, G., Piskorski, T. and Seru, A. (2018) 'Fintech, regulatory arbitrage, and the rise of shadow banks', Journal of Financial Economics, Vol. 130, No. 3, pp.453-483.

Burns, S. (2018) 'M-Pesa and the 'market-led' approach to financial inclusion', Economic Affairs, Vol. 38, No. 3, pp.406-421.

Cai, C.W. (2018) 'Disruption of financial intermediation by FinTech: a review on crowdfunding and blockchain', Accounting and Finance, Vol. 58, No. 4, pp.965-992.

Caron, F. (2018) 'The evolving payments landscape: technological innovation in payment systems', IT Professional, Vol. 20, No. 2, pp.53-61.

Chen, L. (2016) 'From Fintech to Finlife: the case of Fintech development in China', China Economic Journal, Vol. 9, No. 3, pp.225-239.

Chiu, I.H-Y. (2017) 'A new era in fintech payment innovations? A perspective from the institutions and regulation of payment systems', Law Innovation and Technology, Vol. 9, No. 2, pp.190-234.

Coetzee, J. (2018) 'Strategic implications of fintech on South African retail banks', South African Journal of Economic and Management Sciences, Vol. 21, No. 1, p.a2455.

Costa-Climent, R. and Martínez-Climent, C. (2018) 'Sustainable profitability of ethical and conventional banking', Contemporary Economics, Vol. 12, No. 4 special issue, pp.519-530. 
Currie, W.L., Gozman, D.P. and Seddon, J.J.M. (2018) 'Dialectic tensions in the financial markets: a longitudinal study of pre- and post-crisis regulatory technology', Journal of Information Technology, Vol. 33, No. 4, pp.304-325.

Davis, K., Maddock, R. and Foo, M. (2017) 'Catching up with Indonesia's fintech industry', Law and Financial Markets Review, Vol. 11, No. 1, pp.33-40.

Deng, H., Huang, R.H. and Wu, Q. (2018) 'The regulation of initial coin offerings in China: problems, prognoses and prospects', European Business Organization Law Review, Vol. 19, No. 3, pp.465-502.

Dhar, V. and Stein, R.M. (2017) 'Economic and business dimensions: FinTech platforms and strategy', Communications of the ACM, Vol. 60, No. 10, pp.32-35.

Dimbean-Creta, O. (2017) Fintech - already new fashion in finance, but what about the future?', Quality - Access to Success, Vol. 18, No. S3, pp.25-29.

Dimbean-Creta, O. (2018) 'Fintech in corporations. Transforming the finance function', Quality Access to Success, Vol. 19, No. S3, pp.21-28.

Dorfleitner, G., Rad, J. and Weber, M. (2017) 'Pricing in the online invoice trading market: first empirical evidence', Economics Letters, December, Vol. 161, pp.56-61.

Du, K. (2018) 'Complacency, capabilities, and institutional pressure: understanding financial institutions' participation in the nascent mobile payments ecosystem', Electronic Markets, Vol. 28, No. 3, pp.307-319.

Duma, F. and Gligor, R. (2018) 'Study regarding Romanian students' perception and behaviour concerning the fintech area with a focus on cryptocurrencies and online payments', Online Journal Modelling the New Europe, Vol. 27, pp.86-106.

Gabor, D. and Brooks, S. (2017) 'The digital revolution in financial inclusion: international development in the fintech era', New Political Economy, Vol. 22, No. 4, pp.423-436.

Gai, K., Qiu, M. and Sun, X. (2018) 'A survey on FinTech', Journal of Network and Computer Applications, Vol. 103, pp.262-273.

Gatteschi, V., Lamberti, F., Demartini, C., Pranteda, C. and Santamaria, V. (2018) 'To blockchain or not to blockchain: that is the question', IT Professional, Vol. 20, No. 2, pp.62-74.

Geranio, M. (2017) 'Fintech in the exchange industry: potential for disruption?', Masaryk University Journal of Law and Technology, Vol. 11, No. 2, pp.245-266.

Gimpel, H., Rau, D. and Röglinger, M. (2018) 'Understanding FinTech start-ups - a taxonomy of consumer-oriented service offerings', Electronic Markets, Vol. 28, No. 3, pp.245-264.

Gomber, P., Kauffman, R.J., Parker, C. and Weber, B.W. (2018) 'On the Fintech revolution: interpreting the forces of innovation, disruption, and transformation in financial services', Journal of Management Information Systems, Vol. 35, No. 1, pp.220-265.

Gomber, P., Koch, J-A. and Siering, M. (2017) 'Digital finance and FinTech: current research and future research directions', Journal of Business Economics, Vol. 87, No. 5, pp.537-580.

Gozman, D., Liebenau, J. and Mangan, J. (2018) 'The innovation mechanisms of fintech start-ups: insights from SWIFT's innotribe competition', Journal of Management Information Systems, Vol. 35, No. 1, pp.145-179.

Gruin, J. and Knaack, P. (2019) 'Not just another shadow bank: Chinese authoritarian capitalism and the 'developmental' promise of digital financial innovation', New Political Economy, Vol. 25, No. 3, pp.370-387.

Huang, R.H. (2018) 'Online P2P lending and regulatory responses in China: opportunities and challenges', European Business Organization Law Review, Vol. 19, No. 1, pp.63-92.

Iman, N. (2018) 'Is mobile payment still relevant in the fintech era?', Electronic Commerce Research and Applications, Vol. 30, pp.72-82. 
Jagtiani, J. and Lemieux, C. (2018) 'Do fintech lenders penetrate areas that are underserved by traditional banks?', Journal of Economics and Business, Vol. 100, pp.43-54.

Jeong, Y.J., Jeon, H.M., Ock, Y.S. and Jeong, S.C. (2018) 'A study on the acceptance factors to use mobile easy remittance service', ICIC Express Letters Part B: Applications, Vol. 9, No. 1, pp.61-67.

Jun, J. and Yeo, E. (2016) 'Entry of FinTech firms and competition in the retail payments market', Asia-Pacific Journal of Financial Studies, Vol. 45, No. 2, pp.159-184.

Kang, J. (2018) 'Mobile payment in fintech environment: trends, security challenges, and services', Human-centric Computing and Information Sciences, Vol. 8, No. 1, p.32.

Karakas, C. and Stamegna, C. (2018) 'Defining a EU-framework for financial technology (Fintech): economic perspectives and regulatory challenges', Law and Economics Yearly Review, Vol. 7, pp.106-129.

Kotarba, M. (2016) 'New factors inducing changes in the retail banking customer relationship management (CRM) and their exploration by the FinTech industry', Foundations of Management, Vol. 8, No. 1, pp.69-78.

Kshetri, N. and Voas, J. (2018) 'Blockchain in developing countries', IT Professional, Vol. 20, No. 2, pp.11-14.

Langley, P. and Leyshon, A. (2017) 'Capitalizing on the crowd: the monetary and financial ecologies of crowdfunding', Environment and Planning A, Vol. 49, No. 5, pp.1019-1039.

Larios-Hernández, G.J. (2017) 'Blockchain entrepreneurship opportunity in the practices of the unbanked', Business Horizons, Vol. 60, No. 6, pp.865-874.

Lee, I. and Shin, Y.J. (2018) 'Fintech: ecosystem, business models, investment decisions, and challenges', Business Horizons, Vol. 61, No. 1, pp.35-46.

Lee, J., Ryu, M.H. and Lee, D. (2019) 'A study on the reciprocal relationship between user perception and retailer perception on platform-based mobile payment service', Journal of Retailing and Consumer Services, Vol. 48, pp.7-15.

Lee, M.R., Yen, D.C. and Hurlburt, G.F. (2018) 'Financial technologies and applications', IT Professional, Vol. 20, No. 2, pp.27-33.

Lee, S. (2017) 'Evaluation of mobile application in user's perspective: case of P2P lending apps in FinTech industry', KSII Transactions on Internet and Information Systems, Vol. 11, No. 2, pp.1105-1115.

Lee, S-H. and Lee, D-W. (2017) 'A study on analysis of FinTech start-ups in conversions period', Journal of Engineering and Applied Sciences, Vol. 12, No. special issue 4, pp.6769-6774.

Leong, C., Tan, B., Xiao, X., Tan, F.T.C. and Sun, Y. (2017) 'Nurturing a FinTech ecosystem: the case of a youth microloan startup in China', International Journal of Information Management, Vol. 37, No. 2, pp.92-97.

Li, G., Dai, J.S., Park, E-M. and Park, S-T. (2017) 'A study on the service and trend of fintech security based on text-mining: focused on the data of Korean online news', Journal of Computer Virology and Hacking Techniques, Vol. 13, No. 4, pp.249-255.

Lui, A. and Lamb, G.W. (2018) 'Artificial intelligence and augmented intelligence collaboration: regaining trust and confidence in the financial sector', Information and Communications Technology Law, Vol. 27, No. 3, pp.267-283.

Magnuson, W. (2018) 'Regulating fintech', Vanderbilt Law Review, Vol. 71, No. 4, pp.1167-1226.

Maier, E. (2016) 'Supply and demand on crowdlending platforms: connecting small and medium-sized enterprise borrowers and consumer investors', Journal of Retailing and Consumer Services, Vol. 33, pp.143-153.

Mamonov, S. and Malaga, R. (2018) 'Success factors in title III equity crowdfunding in the United States', Electronic Commerce Research and Applications, Vol. 27, pp.65-73. 
Martínez-Climent, C., Zorio-Grima, A. and Ribeiro-Soriano, D. (2018) 'Financial return crowdfunding: literature review and bibliometric analysis', International Entrepreneurship and Management Journal, Vol. 14, No. 3, pp.527-553.

Minto, A., Voelkerling, M. and Wulff, M. (2017a) 'The good, the bad and the ugly: differentiating fintech from a financial stability perspective', Law and Economics Yearly Review, Vol. 6, pp.104-143.

Minto, A., Voelkerling, M. and Wulff, M. (2017b) 'Separating apples from oranges: identifying threats to financial stability originating from FinTech', Capital Markets Law Journal, Vol. 12, No. 4, pp.428-465.

Mooney, C.W. (2018) 'Fintech and secured transactions systems of the future', Law and Contemporary Problems, Vol. 81, No. 1, pp.1-20.

Nakashima, T. (2018) 'Creating credit by making use of mobility with FinTech and IoT', IATSS Research, Vol. 42, No. 2, pp.61-66.

Nam, K., Lee, Z. and Lee, B.G. (2016) 'How internet has reshaped the user experience of banking service?', KSII Transactions on Internet and Information Systems, Vol. 10, No. 2, pp.684-702.

$\mathrm{Ng}$, A.W. and Kwok, B.K.B. (2017) 'Emergence of fintech and cybersecurity in a global financial centre: strategic approach by a regulator', Journal of Financial Regulation and Compliance, Vol. 25, No. 4, pp.422-434.

Ozili, P.K. (2018) 'Impact of digital finance on financial inclusion and stability', Borsa Istanbul Review, Vol. 18, No. 4, pp.329-340.

Petrushenko, Y., Kozarezenko, L., Glinska-Newes, A., Tokarenko, M. and But, M. (2018) 'The opportunities of engaging FinTech companies into the system of crossborder money transfers in Ukraine', Investment Management and Financial Innovations, Vol. 15, No. 4, pp.332-344.

Pousttchi, K. and Dehnert, M. (2018) 'Exploring the digitalization impact on consumer decision-making in retail banking', Electronic Markets, Vol. 28, No. 3, pp.265-286.

Puschmann, T. (2017) 'Fintech', Business and Information Systems Engineering, Vol. 59, No. 1, pp.69-76.

Qi, B.Y. and Xiao, J. (2018) 'Fintech: AI powers financial services to improve people's lives', Communications of the ACM, Vol. 61, No. 11, pp.65-69.

Ranade, A. (2017) 'Role of 'fintech' in financial inclusion and new business models', Economic and Political Weekly, Vol. 52, No. 12, pp.125-128.

Rastogi, C. (2018) 'M-Kopa solar: lighting up the dark continent', South Asian Journal of Business and Management Cases, Vol. 7, No. 2, pp.93-103.

Riikkinen, M., Saraniemi, S. and Still, K. (2019) 'Fintechs as service innovators - understanding the service innovation stack', International Journal of e-Business Research, Vol. 15, No. 1, pp.20-37.

Romanova, I., Grima, S., Spiteri, J. and Kudinska, M. (2018) 'The payment services directive II and competitiveness: the perspective of European fintech companies', European Research Studies Journal, Vol. 21, No. 2, pp.3-22.

Ryu, H-S. (2018) 'What makes users willing or hesitant to use fintech?: The moderating effect of user type', Industrial Management and Data Systems, Vol. 118, No. 3, pp.541-569.

Saksonova, S. and Kuzmina-Merlino, I. (2017) 'Fintech as financial innovation - the possibilities and problems of implementation', European Research Studies Journal, Vol. 20, No. 3, pp.961-973.

Savoie, R. and Hoffman, P.P.J. (2018) 'Marketplace lending and fintech: the states object', Business Lawyer, Vol. 73, No. 2, pp.509-516. 
Schulte, P. and Liu, G. (2018) 'Fintech is merging with IoT and AI to challenge banks: how entrenched interests can prepare', Journal of Alternative Investments, Vol. 20, No. 3, pp.41-57.

Shim, Y. and Shin, D-H. (2016) 'Analyzing China's fintech industry from the perspective of actor-network theory', Telecommunications Policy, Vol. 40, Nos. 2-3, pp.168-181.

Sinha, S. (2017) 'A glimpse into the world of FinTech accelerators - the open vault at OCBC', IEEE Potentials, Vol. 36, No. 6, pp.20-23.

Sinha, S., Pandey, K.R. and Madan, N. (2018) 'Fintech and the demand side challenge in financial inclusion', Enterprise Development and Microfinance, Vol. 29, No. 1, pp.94-98.

Sloboda, L., Dunas, N. and Limański, A. (2018) 'Contemporary challenges and risks of retail banking development in Ukraine', Banks and Bank Systems, Vol. 13, No. 1, pp.88-97.

Son, I. and Kim, S. (2018) 'Mobile payment service and the firm value: focusing on both up- and down-stream alliance', Sustainability (Switzerland), Vol. 10, No. 7, pp.25-83.

Stern, C., Makinen, M. and Qian, Z. (2017) 'FinTechs in China - with a special focus on peer to peer lending', Journal of Chinese Economic and Foreign Trade Studies, Vol. 10, No. 3, pp.215-228.

Stewart, H. and Jürjens, J. (2018) 'Data security and consumer trust in FinTech innovation in Germany', Information and Computer Security, Vol. 26, No. 1, pp.109-128.

Stoeckli, E., Dremel, C. and Uebernickel, F. (2018) 'Exploring characteristics and transformational capabilities of InsurTech innovations to understand insurance value creation in a digital world', Electronic Markets, Vol. 28, No. 3, pp.287-305.

Sutherland, A. (2018) 'Does credit reporting lead to a decline in relationship lending? Evidence from information sharing technology', Journal of Accounting and Economics, Vol. 66, No. 1, pp.123-141.

Sybirianska, Y., Dyba, M., Britchenko, I., Ivashchenko, A., Vasylyshen, Y. and Polishchuk, Y. (2018) 'Fintech platforms in SME's financing: EU experience and ways of their application in Ukraine', Investment Management and Financial Innovations, Vol. 15, No. 3, pp.83-96.

Tao, Q., Dong, Y. and Lin, Z. (2017) 'Who can get money? Evidence from the Chinese peer-to-peer lending platform', Information Systems Frontiers, Vol. 19, No. 3, pp.425-441.

Trelewicz, J.Q. (2017) 'Big data and big money: the role of data in the financial sector', IT Professional, Vol. 19, No. 3, pp.8-10.

Tsai, C-H. and Peng, K-J. (2017) 'The FinTech revolution and financial regulation: the case of online supply-chain financing', Asian Journal of Law and Society, Vol. 4, No. 1, pp.109-132.

Upton, E.J. (2018) 'Chartering FinTech: the OCC's newest nonbank proposal', George Washington Law Review, Vol. 86, No. 5, pp.1392-1437.

Van Loo, R. (2018) 'Making innovation more competitive: the case of fintech', UCLA Law Review, Vol. 65, No. 1, pp.232-279.

Wonglimpiyarat, J. (2017a) 'FinTech banking industry: a systemic approach', Foresight, Vol. 19, No. 6, pp.590-603.

Wonglimpiyarat, J. (2017b) 'FinTech crowdfunding of Thailand 4.0 policy', Journal of Private Equity, Vol. 21, No. 1, pp.55-63.

Wonglimpiyarat, J. (2018) 'Challenges and dynamics of FinTech crowd funding: an innovation system approach', Journal of High Technology Management Research, Vol. 29, No. 1, pp.98-108.

Yang, D. and Li, M. (2018) 'Evolutionary approaches and the construction of technology-driven regulations', Emerging Markets Finance and Trade, Vol. 54, No. 14, pp.3256-3271.

Yoon, K-S. and Jun, J. (2019) 'Liability and antifraud investment in fintech retail payment services', Contemporary Economic Policy, Vol. 37, No. 1, pp.181-194. 
Yue, X., Shu, X., Zhu, X., Du, X., Yu, Z., Papadopoulos, D. and Liu, S. (2019) 'BitExTract: interactive visualization for extracting Bitcoin exchange intelligence', IEEE Transactions on Visualization and Computer Graphics, Vol. 25, No. 1, pp.162-171.

Zalan, T. and Toufaily, E. (2017) 'The promise of fintech in emerging markets: not as disruptive', Contemporary Economics, Vol. 11, No. 4, pp.415-430.

Zetzsche, D. and Preiner, C. (2018) 'Cross-border crowdfunding: towards a single crowdlending and crowdinvesting market for Europe', European Business Organization Law Review, Vol. 19, No. 2, pp.217-251. 